\title{
An enzymatic method for the detection of human serum albumin
}

\author{
Masood-ul-Hassan Javed ${ }^{1,2}$ \\ and Saima N. Waqar ${ }^{1}$ \\ ${ }^{1}$ Department of Biochemistry, The Aga Khan University Medical \\ College, Stadium Road, Karachi 74800, Pakistan \\ ${ }^{2}$ Corresponding author: Tel, +00-92-51-4446801-Ext: 3364; \\ Fax, +00-92-51-4435046; E-mail, masoodjaved@ hotmail.com
}

Accepted 4 June 2001

Abbreviations: DB, dextran blue; HSA, human serum albumin; LDH, lactate dehydrogenase; CSF, cerebrospinal fluid

\begin{abstract}
Albumin is the most abundant protein in human serum. A dye-binding method is commonly used in clinical laboratories for its estimation using different types of dyes. However, all these dye methods were interfered by a variety of compounds. Here we present a method for the detection of albumin in human serum and other biological fluids. The principle is based on the fact that lactate dehydrogenase isoenzyme-5 (LDH-5) binds specifically to DextranBlue (DB). Albumin inhibits the binding of LDH-5 with DB. Absence of LDH activity in DB fraction after gel filtration indicates the presence of albumin in sample and vice versa.
\end{abstract}

Keywords: albumin, human, LDH-5, serum

\section{Introduction}

Human serum albumin (HSA) is synthesized in liver and is the most abundant protein in human serum, representing $40-60 \%$ of the total protein (Lindsey, 1996). The earliest method for its determination involved the saltingout of the globulins with sodium sulfate, leaving the albumin in solution (Silverman and Christenson, 1994). The albumin was then determined by the Kjeldahol method and, later, by the Biuret color development (Gomes et al., 1998). The method commonly used today is one involving dye binding and shift in color when a dye is bound by albumin (Silverman and Christenson, 1994; Lindsey, 1996; Gomes et al., 1998). A variety of dyes have been used, including methyl orange, 2-(4'hydroxyazobenzene) benzoic acid (HABA), bromocresol green (BCG), and bromocresol purple (BCP) (Thakkar et al., 1997; Kessler et al., 1997a). Methyl orange is non-specific for albumin; $\beta$-lipoproteins and some $\alpha 1$ and $\alpha 2$-globulins also bind to albumin and have a low sensitivity (Kessler et al., 1997a). In addition, several compounds such as salicylates, penicillin, conjugated bilirubin, and sulfonamides, interfere with the binding of albumin to the dye. Interfering substances such as bilirubin and salicylates do not affect BCG; however, hemoglobin can inhibit the binding of albumin to dye (Kessler et al., 1997b). Even though BCG is the dye most commonly used today, there are repeated reports that the measurement of albumin by BCG overestimates albumin levels (Karon et al., 1997). Several formats of electrophoresis, radioimmunoassays (RIA) and immunoassays are available for albumin determination (Karon et al., 1997; Kessler et al., 1997b), which are more appropriate for body fluids in which albumin concentration is normally low (i.e., urine and CSF). The RIA and immunoassays are relatively expensive and unlikely to be applied except for special diagnostic purposes. Recently, the albumin-blue (AB) series of fluorescent albumin dyes have been described (Kessler et al., 1997a). The limited solubility of the reagent solution so far prevented its application in routine analysis. A new derivative of $A B, A B 580$, with improved solubility has become available recently and is used in autoanalyser for albumin determination in serum and urine (Karon et al., 1997). Except for blood serum, albumin concentrations in body fluids such as urine are usually low and, therefore, require sensitive and selective method for their detection and estimation. Enzymes have been extensively used nowadays in the analytical laboratories due to their high specificity and sensitivity (Whitaker, 1991; Rej, 1998). In this study we present a simple method for the detection of human albumin in biological sample using LDH-5 and DB.

\section{Materials and Methods}

\section{Chemicals}

$\mathrm{NADH}$, sodium pyruvate, Dextran Blue (DB), human serum albumin (HSA), bovine serum albumin (BSA) and potassium phosphate were from Sigma, St. Louis, U.S.A. Sepharose-CL-6B gel was from Pharmacia-LKB Biotechnology, Uppsala, Sweden. The LDH-5 was purified from rat liver as described elsewhere (Javed et al., 1995). All biological fluids were obtained from the clinical laboratory of the Aga Khan University Hospital 
(AKUH) and assayed after centrifugation within 3 days. This study followed the protocol of the Human Subject Protection Committee of AKUH and all volunteers were informed prior to participation.

\section{Principle of the assay}

This assay is based on high affinity binding of DB with LDH-5 (Leatherbarrow and Dean, 1980; Javed and Naru, 1998; Javed et al., 1999). This binding of LDH-5 with DB was specifically inhibited by HSA (Javed and Naru, 1998; Javed et al., 1999). The presence of the $\mathrm{LDH}$ activity in DB fraction after gel filtration indicates the absence of albumin while the absence of $\mathrm{LDH}$ activity indicates the presence of albumin.

\section{Procedure}

The Sepharose-CL-6B gel was packed in column (17 $\mathrm{cm} \times 0.5 \mathrm{~cm}$ ) and equilibrated with $10 \mathrm{mM}$ potassium phosphate buffer containing $0.02 \%$ sodium azide, $\mathrm{pH}$ 7.5. One $\mathrm{mg} \mathrm{DB}$ was added to $1 \mathrm{ml}$ sample ( $\pm \mathrm{HSA})$ and applied on top of the column. The microfractionator (Gilson, Wisconsin, USA) collected one $\mathrm{ml}$ fractions and the flow rate was controlled to about $40 \mathrm{ml} / \mathrm{h}$ by Microperpex peristaltic pump (LKB, Ujppsala, Sweden). To measure LDH activity, we added $465 \mu$ l of DB fraction to $1 \mathrm{ml}$ cuvette. Twenty five $\mu \mathrm{l}$ substrate buffer (12 mM sodium pyruvate and $1 \mathrm{M}$ potassium phosphate $\mathrm{pH} 7.5$ ) were mixed and kept at $30^{\circ} \mathrm{C}$ for about $10 \mathrm{~min}$. The reaction was then started by adding $10 \mu \mathrm{l}$ of $0.9 \mathrm{mM}$ $\mathrm{NADH}$ and the rate was monitored at $340 \mathrm{~nm}$ in spectrophotometer (Beckman DU70, USA) for 2-3 min (Javed et al., 1995; Javed and Naru 1998).

\section{Results}

In the presence of DB in the samples, LDH-5 co-eluted with $\mathrm{DB}$ in void volume of sepharose column (Figure 1). However, in the presence of HSA in samples along with DB, LDH-5 activity was absent from DB fractions and eluted in later fractions of column chromatography (Figure 1). All human body fluids that contained albumin (serum, albuminuric urine, plural fluid, ascites, peritonial fluids, etc) showed no LDH-5 activity in DB fractions after gel filtration and LDH-5 activity was observed in the later fractions. The minimum volume of normal human serum needed to completely block the LDH-5 binding with $\mathrm{DB}$ was found to be $2 \mu \mathrm{l}$, that equals to be about $0.08 \mathrm{mg}$ of albumin. We tried to estimate the albumin by calibrating a standard curve but we could not reproduce the results. By adding serum to DB-LDH samples from animals (i.e., animal albumin) like sheep, rabbit, mouse, rat, hamster and pigeon, the DB-LDH complex appeared in void volume. There was no effect on binding of DB with $\mathrm{LDH}-5$ even up to $40 \mathrm{mg} / \mathrm{ml}$ of animal albumin.

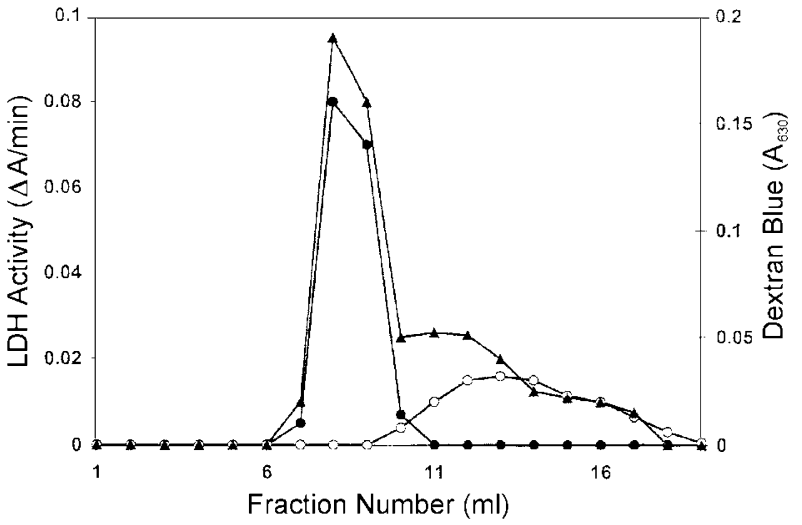

Figure 1. Gel filtration of DB-LDH-complex in the presence $(\bigcirc-\bigcirc)$ and absence (-) of human serum albumin. The method is described in the text. DB peak is shown as $(\boldsymbol{\Delta}-\mathbf{\Delta})$ which is eluted in the void volume. The pattern of the Fig was like (-) when we added the serum in the samples from various animal species or BSA as mentioned in the results.

Similarly there was no effect of BSA on the binding of DB with LDH-5.

\section{Discussion}

Various methods have been used for the detection of albumin in different biological samples (Karon et al., 1997; Kessler et al., 1997a; Kessler et al., 1997b; Thakkar et al., 1997). Each method has some merits and demerits and the major drawback is the interference by other proteins and metabolites (Kessler et al., 1997a). Here, we described a new method for the detection of HSA. We believe that the gel filtration method is more specific than the dye binding methods (Karon et al., 1997; Kessler et al., 1997a; Kessler et al., 1997b; Thakkar et al., 1997) because the DB specifically binds to LDH-5 and it does not have any affinity even for $\mathrm{LDH}-1$. Similarly, the HSA specifically compete with the binding of LDH-5 with DB and albumin from other animals and other serum proteins from human serum do not compete with binding of DB with LDH-5 (Leatherbarrow and Dean, 1980). We have also observed that the binding of DB with LDH-5 is inhibited only by HSA, as the serum from animals, like sheep, rabbit, mouse, rat, hamster and pigeon (which contained animal albumin and not human albumin) were unable to block the binding of LDH-5 with DB and LDH activity appeared in the void volume in the presence of even up to $40 \mathrm{mg} / \mathrm{ml}$ of animal albumin (speculating that these animal serum also have about $4 \mathrm{gm} / \mathrm{dl}$ of albumin with total serum protein as about $6-8 \mathrm{gm} / \mathrm{dl})$. This method is more simple and sensitive to detect micro quantity of albumin. The same gel has been used for many months and even can be used for many years in the presence of $0.02 \%$ sodium azide. Furthermore, LDH-5 can easily be purified in large quantities from rat liver (Javed et al., 1995) 
and was found to be stable for years at $4^{\circ} \mathrm{C}$.

In conclusion, the detection of HSA in biological fluids by this method is more specific relative to dye binding methods and can be applied in many pathological conditions. The dye binding and electrophoresis are standard but need special equipments, which may not be available in ordinary clinical laboratories, particularly in developing countries. Furthermore this new assay for HSA detection is a useful addition to the analytical sciences.

\section{Acknowledgements}

We gratefully thank to Miss Farzana A. Yousuf for her technical help.

\section{References}

Gomes MB, Dimetz T, Luchetti MR, Goncalves MF, Gazzola $\mathrm{H}$, Matos $\mathrm{H}$. Albumin concentration is underestimated in frozen urine. Ann Clin Biochem 1998;35:434-35

Javed $M H$, Yousuf FA, Hussain AN, Ishaq M, Waqar MA. Purification and properties of LDH from liver of Uromastix hardwickii. Comp Biochem Physiol 1995;111B:27-34

Javed MH, Naru TY. A simple method for the detection of LDH isoenzyme M:H ratio by gel filtration. Ann Clin Biochem 1998; 35:439-41

Javed MH, Jafri AH, Yousuf FA. Detection of LDH isoenzyme$\mathrm{M}$ in body fluids containing albumin. Ann Clin Biochem 1999;

\section{6:250-51}

Karon BS, Kampe KC, Scott MG. Heparin interference with sodium and albumin assays. Clin Chem 1997;43:697-98

Kessler MA, Meinitzer A, Petak W, Wolfbeis OS. Microalbuminuria and borderline-increased albumin excretion determined with a centrifugal analyzer and the albumin blue 580 fluorescence assay. Clin Chem 1997a;443:996-1002

Kessler MA, Meinitzer A, Wolfbeis OS. (1997b) Albumin blue 580 fluorescence assay for albumin. Anal Biochem 1997b; 248:180-82

Leatherbarrow RJ., Dean DG. Studies on the mechanism of binding of serum albumins to immobilized cibacron blue F3GA. Biochem J 1980;189:27-34

Lindsey BJ. Amino acids and proteins. In Clin. chem.: principles, procedures, correlation (ed M.L. Bishop, J.L. Duben-Engelkirk \& E.P. Fody, EP), 1996, pp. 169-214. Philadelphia: J. B. Lippincott Co.

Rej R. They use enzymes for every things! Clin Chem 1998;44:1149-53

Silverman LM. Christenson RH. Amino acids and proteins In Tietz text book of clinical chemistry (ed C. A. Burtis \& E. R. Ashwood), 1994, pp. 191-205. Philadelphia: W. B. Saunders Co.

Thakkar H, Newman DJ, Holownia P, Davey CL, Wang CC, Lloyd J, Graig AL, Price CP. Development and validation of a particle-enhanced turbidimetric inhibition assay for urine albumin on the ACA analyzer. Clin Chem 1997;43:109-13

Whitaker JR. Enzymes in analytical chemistry, In Food enzymology (ed P. F. Fox), 1991, pp. 287-308. London: Elsevier Applied Science. 